\title{
Career learning and career learning environment in Dutch higher education
}

Citation for published version (APA):

Meijers, F., \& Kuijpers, M. (2014). Career learning and career learning environment in Dutch higher education. Journal of Applied Research in Higher Education, 6(2), 295-313. https://doi.org/10.1108/JARHE-06-2013-0025

DOI:

10.1108/JARHE-06-2013-0025

Document status and date:

Published: 02/09/2014

Document Version:

Publisher's PDF, also known as Version of record

Document license:

CC BY-SA

Please check the document version of this publication:

- A submitted manuscript is the version of the article upon submission and before peer-review. There can be important differences between the submitted version and the official published version of record. People interested in the research are advised to contact the author for the final version of the publication, or visit the DOI to the publisher's website.

- The final author version and the galley proof are versions of the publication after peer review.

- The final published version features the final layout of the paper including the volume, issue and page numbers.

Link to publication

\section{General rights}

Copyright and moral rights for the publications made accessible in the public portal are retained by the authors and/or other copyright owners and it is a condition of accessing publications that users recognise and abide by the legal requirements associated with these rights.

- Users may download and print one copy of any publication from the public portal for the purpose of private study or research.

- You may not further distribute the material or use it for any profit-making activity or commercial gain

- You may freely distribute the URL identifying the publication in the public portal.

If the publication is distributed under the terms of Article 25fa of the Dutch Copyright Act, indicated by the "Taverne" license above, please follow below link for the End User Agreement:

https://www.ou.nl/taverne-agreement

Take down policy

If you believe that this document breaches copyright please contact us at:

pure-support@ou.nl

providing details and we will investigate your claim.

Downloaded from https://research.ou.nl/ on date: 26 Apr. 2023 


\section{Career learning and career learning environment in Dutch higher education}

\author{
Frans Meijers \\ Research Group Pedagogy of Career Development, \\ The Hague University of Applied Sciences, The Hague, The Netherlands, and \\ Marinka Kuijpers \\ LOOK, Open University, Heerlen, The Netherlands
}

\section{Career learning environment}

295

Received 25 June 2013 Revised 17 September 2013 Accepted 20 November 2013

\begin{abstract}
Purpose - The purpose of this paper is to focus on the effects of career development and guidance among students (age 17-23) enrolled in higher education in The Netherlands. First the paper explores whether the development of career competencies contribute to career identity, learning motivation, certainty of career choice and drop out, and also whether the learning environment affects these variables. In the study, four career competencies are identified: career reflection (reflective behavior), work exploration (exploring behavior), career action (pro-active behavior) and networking (interactive behavior). Aspects of the learning environment that are taken into account are practice- and inquiry-based curriculum and career guidance conversations.

Design/methodology/approach - A questionnaire-based study was carried out among 4,820 students and 371 (school) career counsellors in 11 universities.

Findings - The results show that career competencies are related to learning motivation, career identity, certainty of career choice and drop out threat. The learning environment also contributes to these outcome variables. Students who participate in a practice-based and inquiry-based curriculum, and who have helping conversations about their study with their teachers, feel more motivated for learning, are more certain of their career choice and are less likely to quit their study.

Research limitations/implications - A limitation of this study is that, due to the cross-sectional design with no control group, no strong evidence for effectiveness can be presented. Moreover, the lack of well validated instruments limits the value of the results. The explained variance of the outcome variables, however, does indicate that there are relationships between career competencies and career learning environment on one hand, and career identity, learning motivation and certainty of choices on the other.

Practical implications - Constructing and attributing meaning when engaging in these dialogues is of central importance; the development of personality traits and qualities only takes place when those learning find the content meaningful (and that is something quite different than content being considered "necessary"). In order to achieve such a learning environment within the dominant educational culture, transformative leadership is essential. Such leadership, however, is rare in Dutch universities of applied sciences until now.

Social implications - Universities are increasingly acknowledging that they have a strong responsibility to guide students not only in their academic growth, but also in their career development. Universities - and especially universities of applied sciences - cannot leave this task to the public or private sector for two key reasons. First, universities are funded by the government and are therefore expected to prepare their students adequately for life in our individualized society as well as for the labor market. In the second place because organizations in the private and public sector often lack the knowledge and the motivation to guide young people on their career paths.
\end{abstract}

Originality/value - A limitation found in the research, as well as in actual career interventions in schools, is that they focus on change in students' knowledge, attitudes and decision-making skills, while students' behaviors are not examined. Hughes and Karp (2004) maintain that research should focus on exploring the relationships between guidance interventions and positive students' behavioral outcomes. Therefore, the paper concentrates - in search of the influence of school-based career

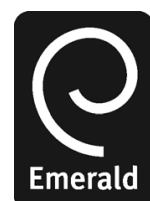

Journal of Applied Research in Higher Education Vol. 6 No. 2,2014 pp. $295-313$

(C) Emerald Group Publishing Limited 2050-7003 
JARHE

6,2 interventions - not on decision-making skills, attitudes or knowledge but on actual career behavior, i.e. career competencies of students.

Keywords Career development, Learning environment

Paper type Research paper

\section{Introduction}

The future of the majority of youngsters is very uncertain. "Grand narratives," that gave identity and direction in life, have disappeared leaving youngsters (and many adults) with the problem how to give meaning to their lives themselves (Giddens, 1991; Beck, 1994; Amundson, 2010). Careers do not develop within clear boundaries anymore and are, therefore, to a large extent unpredictable (Arthur et al., 2005; Pryor and Bright, 2011). At the same time, however, youngsters are expected to be intrinsically motivated when they enter the labor market, because the personalities of employees in a service economy are becoming an increasingly important production factor (Sennett, 1998; Irving and Malik, 2005; Bimrose and Hearne, 2012). Thirty years ago, 100 percent of the vacancy descriptions for jobs requiring higher education in the Netherlands, clearly noted what the required education was, 50 percent described the necessary work experience and 20 percent outlined the preferred interest for the job (Van Beek, 1993). Nowadays, all vacancy descriptions contain general competencies, of which half relate to employability and personal development in terms of flexibility, learning ability and reflective and pro-active behavior. Even for jobs in for-profit organizations, qualities such as passion, ambition and self-development are listed under the requirements (Kuijpers, 2007).

Universities are, therefore, increasingly acknowledging that they have a strong responsibility to guide students not only in their academic growth, but also in their career development (Jarvis and Keeley, 2003; Gysbers and Henderson, 2005). Universities - and especially universities of applied sciences - cannot leave this task to the public or private sector for two key reasons. First, universities are funded by the government and are therefore expected to prepare their students adequately for life in our individualized society as well as for the labor market (Kronman, 2007; Trilling and Fadel, 2009; Wagner, 2010). In the second place because organizations in the private and public sector often lack the knowledge and the motivation to guide young people on their career paths (Johnson, 2009; Organisation for Economic Co-operation and Development, 2006). They assume - as their personnel ads frequently demonstrate that aspiring workers have made a clear career choice when they enter an organization. Universities can also not leave the task to students, as brain research shows they are seldom able to make these choices without guidance (Schwartz, 2004; Stuss and Anderson, 2003; Meijers and Lengelle, 2012).

In Dutch universities, a mismatch exists between "theory in use" and "espoused theory" (Argyris and Schön, 1974). The espoused theory states that students - in order to deal with the effects of the individualization of society, the emergence of an unpredictable career and the growing emotionalization of work - have to develop not only career competencies (Kuijpers and Scheerens, 2006) but also a career identity (Savickas et al., 2010). Career identity can be defined as a story told by a person, expressing his/her life theme(s) and the way (s)he identifies her/himself based on these life theme(s) with a specific occupation or career (Ashforth et al., 2008). Life themes provide the unity in life (hi)stories and can be viewed as "an existing and enduring orientation that guides interpretation and action" (Cochran, 1997, p. 60). A career story helps a person to define who one is and how one should act in the changing career 
context, by giving meaning and direction (Wijers and Meijers, 1996; Meijers and Lengelle, 2012; Lengelle et al., 2013). The theory in use, however, is still predominantly the trait-and-factor approach (European Commission and OECD, 2004; Organisation for Economic Co-operation and Development (OECD), 2004; Sultana, 2004; Irving and Malik, 2005; Watts and Sultana, 2004; Reid and West, 2011). In this approach focus is placed on achieving the best possible match between the skills of an individual and the "right" education, training or job opportunities. It is assumed that students can match their skills with education, training or job opportunities efficiently, if they have enough information about their own skills, preferences and personality and the educational, training or job requirements. Many scholars, however, have argued that there is little research supporting the trait-and-factor approach as a viable way of career development; especially its usefulness in fluid labor market conditions has been questioned, since matching assumes a degree of stability (Mitchell and Krumboltz, 1996; Sharf, 1997; Krumboltz and Worthington, 1999; Pryor and Bright, 2011). Career paths have become unpredictable and research and practice show that it is no longer possible to make career choices in a purely rational and information-based way (Mitchell et al., 1999; Guindon and Hanna, 2002; Krieshok et al., 2009; Savickas, 2013). It is, therefore, not surprising that students overall are negative about the guidance they receive and to a large extent consider it useless (Mittendorff, 2010; Foskett, 2004).

At the same time, however, it is clear that the managers responsible for guidance in universities have little or no vision regarding career guidance and counselling that aims at the development of career competencies and a career identity. They simply invest in providing information (mainly because the costs are much lower than providing narrative career guidance), while at the same time expecting that students acquire a career identity (Kuijpers and Meijers, 2012). In part, the lack of a clear vision among managers is the result of the lack of consensus about what constitutes effective career guidance in an educational context (Law, 2005; OECD, 2004).

\section{The effects of education-based career development: an overview}

Despite it's shortcomings, the trait-and-factor model is dominant in effect studies. Sampson et al. (2003) suggest that the apparent lack of progress in the development of useful accountability-based and evaluation models is linked to the absence of conceptual and operational constructs that define the outputs of career service interventions. The trait-and-factor model, however, offers clear constructs that are relatively easy to measure: "informed choice" and - along with that - "decision making." Almost all effect studies concentrate on the question if a specific guidance intervention results in more informed choices and/or better decision making; only a few researchers concentrate on the process of guidance (Bimrose et al., 2004).

When it comes to guidance, research shows that the focus of careers education and guidance is mainly on helping students with their academic achievement and not on helping students plan and prepare for their work roles afterwards (Parsad et al., 2003; Meijers, 2001, 2008). There is evidence, however, scattered, that in terms of careeridentity development the latter affects a number of outcome measures. Oliver and Spokane (1988) and Whiston et al. (1998) show that career interventions that try to help students plan and prepare for their work roles, have the most impact on the development of career decision-making skills, as compared to other possible skills (such as career-related knowledge or career-related self-concept development). These results are confirmed by Savickas (1990), Brusoski et al. (1993) and McWhirter et al. (2000) who showed that students who took a career-decision-making course
Career learning environment 
JARHE

6,2

298 demonstrated less career-related indecision at the end of the course than did a comparison group. O'Hara (cited in Hughes and Karp, 2004, p. 22) and Lent et al. (1986) found a positive relationship between participation in a career course and increased scores on an inventory of career orientation, indicating that students are engaged in increased career planning and career exploration. Killeen et al. (1999) show that participation in The Real Game - a game that forces participants to make career decisions - results in an increase of knowledge of work and occupations. Knowing how the world of work is organized, eases the process of vocational decision making and job transition. Especially important is the acquisition of a "compact view of the world of work at a more manageable level of abstraction" (Dawis, 1996, p. 239). Career interventions, that help individuals to gain self-knowledge about where they can be satisfactory and satisfied workers, also ease occupational choice-making and enhance work adjustment (Savickas, 2002). Hughes et al. (2002), Killeen (1996) and Killeen et al. (1992) show that effective guidance has "immediate outcomes," especially enhanced knowledge and skills including the ability to create effective transitions, change attitudes including building self-confidence and esteem, which increases motivation and the willingness to consider new employment or learning options. Riverin-Simard (2000) and Harrington and Harrigan (2006) conclude that of the different types of career guidance interventions, individual counseling interventions are the most effective. However, according to Hughes and Karp (2004), there is little evidence that any of these gains - either academic or career-related - are maintained over time.

\section{Research question and research model}

A limitation found in the research, as well as in actual career interventions in schools, is that they focus on change in students' knowledge, attitudes and decision-making skills, while students' behaviors are not examined. Hughes and Karp (2004) maintain that research should focus on exploring the relationships between guidance interventions and positive students' behavioral outcomes. Therefore, we concentrate - in search of the influence of school-based career interventions - not on decision-making skills, attitudes or knowledge but on actual career behavior, i.e. career competencies of students. Career competencies, according to Kuijpers and Scheerens (2006), include the following items: making concrete the thinking about one's own motivation and aptitudes (career reflection), giving shape to one's own career path by exploring the options in study and work (career exploration), truly steering one's own learning process (career action), and building and maintaining of a network (networking). Previous research (Kuijpers et al., 2011; Kuijpers and Meijers, 2012; Meijers et al., 2013), that focussed on the relation between career competencies and the learning environment, showed a dominant approach in education, in which knowledge about person and environment for the most part is not based on real-life experiences with work. Instead, "career knowledge" is created by instruments and professionals and transmitted by standardized methods that are not aimed at the creation of personal meaning via dialogue, and do not support the development and use of career competencies. A learning environment, however, that stimulates real-life experiences with work and a dialogue about these experiences does contribute to the use of career competencies. Even when personality traits of the students and their education are taken into account, we see that the characteristics of the learning environment influence most the degree to which and the kind of career competencies learned and used by students. In particular, the career dialogue with teachers and the conversation students have in the workplace with professionals has proven to be 
crucial. Both contribute to career reflection, career exploration, career-action, and networking; this dialogue is also more strongly correlated with the development of career competencies than personality traits are.

As stated before, employers expect new employees to have more intrinsic motivation than three decades ago. Most students, however, are more extrinsically (i.e. getting a degree) than intrinsically (i.e. becoming a professional in a specific occupational context) motivated when they enter university (Prawat, 1998; Light, 2001; Hargreaves, 2003; Nichols and Berliner, 2007). The reason for this is that the majority of students - at least in the first two years of their study - is uncertain about their career choice, leading to a high drop-out rate (Dieleman and Meijers, 2005). Building on previous research regarding the relationship between career competencies and learning environment (Kuijpers and Meijers, 2012; Kuijpers et al., 2011), we want to investigate the effect of career competencies on career identity, learning motivation, certainty of career choice and threat of drop out.

The research presented here has an explorative character and aims to provide an answer to the following question:

What is the relationship between career competencies on the one hand and career identity, learning motivation, certainty of career choice and drop out threat on the other hand, when we control for personal and situational factors and account for the influence of the learning environment?

The variables that have been taken into consideration and the relationships that have been analyzed in this study, are shown in Figure 1. All arrows between blocks of variables represent regression coefficients between all predictor and all predicted variables.

\section{Method}

Sample

The study sample is drawn mainly from students of 11 universities of applied sciences. The study programs offered by universities of applied sciences are career oriented. Acquiring practical work experience through internships is an integral part of professional study programs. These universities have less status than research universities, but function under the same laws and rules as research universities. The sample was drawn via a multi-stage process. In the first stage, representatives of all 41 universities of applied sciences in The Netherlands were invited to a conference

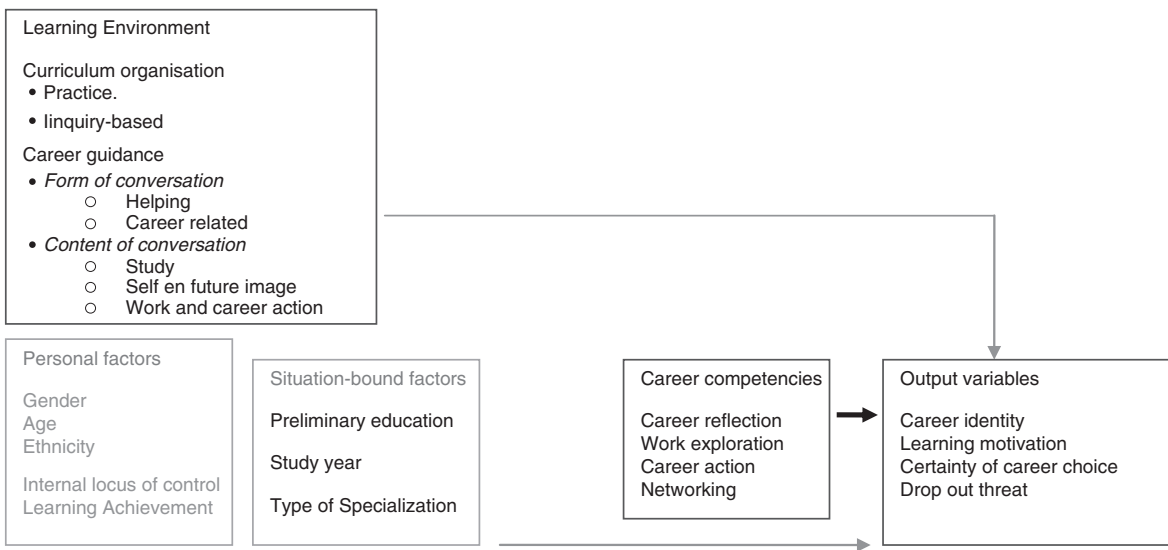

Career learning environment

299 
JARHE

6,2

300 concerning career guidance and counseling, organized by LOPA (the National Platform for Personnel and Labor) in Fall 2007. Representatives of the attending universities were approached by the researchers and asked whether they would like to participate in the present study. Teachers - and their students - were then selected by each positively responding university, and were asked to participate. Participating universities were spread throughout The Netherlands, and covered inner-city as well as rural regions. There are no significant differences between participating and non-participating universities with respect to size, university population (especially with respect to gender and ethnicity), and environment (urban vs rural). However, participating departments of the universities are likely more positive toward career guidance and counseling than non-participating departments. The questionnaire was completed in person during a class in groups of 15-35 students; at the same time the teacher completed a questionnaire. One of the researchers was present to introduce the research project and to answer questions. Participation was voluntary and anonymity was guaranteed. The sample is hierarchically structured. Three levels can be distinguished: students are nested in groups per teacher, which are in turn nested within institutes. Therefore a multi-level analysis approach is chosen by which the hierarchical data structure can be appropriately handled.

\section{Construction of instruments}

The instrument used for collecting data from the students, a self-evaluation-based questionnaire of 129 items, was developed in five phases. First of all, an analysis was made of existing questionnaires in the area of career development. Since no existing instrument was found that was directly useful for this study, the questionnaire of Kuijpers and Scheerens (2006) became the foundation of the instrument used here to measure career competencies. Second, a pilot questionnaire was presented to eighteen students by way of interviews. Each individual item of this pilot questionnaire was discussed with each student. The questionnaire was consequently amended and then evaluated by a language expert and a methodologist. Third, the questionnaire was presented to 200 students for an examination of the psychometric performance of the items and scales, with the intention of possibly culling the number of items for the definitive questionnaire. Finally, for an evaluation of the face validity the results of the process were presented to a board of experts in the field of career development.

The questionnaire consisted of the following components.

Career competencies: based on Arthur et al. (1999), Kuijpers and Scheerens (2006) originally distinguished five career competencies; in the research presented here a four factor model of career competencies fitted best (tested by confirmatory factor analyses with MPLUS version 4.2). The four factor model obtained a $\chi^{2}$ equal to 7,869 with $\mathrm{df}=428$, and a RMSEA equal to 0.06 . CFI and TLI were equal to 0.83 and 0.81 , respectively. This indicated that the data deviated significantly from the predictions of the model. The four factor model contains career-reflection (characterized by reflective behavior), work exploration (characterized by exploring behavior), career action (characterized by pro-active behavior) and networking (characterized by interactive behavior). The response categories of the items vary from $1=$ strongly agree to $5=$ strongly disagree. The variables demonstrate adequate internal consistency (Cronbachs $\alpha 0.74$ to 0.84 ). Career reflection was measured by 11 items. An example item is: "I use experiences that make me feel happy in order to find out what I really consider important in life." Work exploration contained seven items, for example: "I explore what the problems are in the work that I study for." Career action was 
measured by seven items, for example, "I do extra things in my training, so that I have more chance at getting interesting/enjoyable work." Networking contained seven items (f.i. "I talk to skilled people about my future plans").

Learning motivation is measured in eight items, based on the contribution of the students in their course of study. This instrument was used and tested in Dutch education by De Bruijn et al. (2005). Example items are: "I work hard at this course of study" and "When I have something to do for this course of study, I start on it right away."

Career identity can be defined as a story told by a person, expressing his/her life theme(s) and the way (s)he identifies her/himself based on these life theme(s) with a specific occupation or career (Ashforth et al., 2008). A career identity is co-constructed, socially situated and performed in interactions. According to Hermans and HermansKonopka (2010) this co-construction is a practice of positioning, whereby "master narratives" (Davies and Harré, 1990) and discourses - as LaPointe (2010, p. 2) puts it "position individuals and construct their identities in the interaction between narrator and audience. [...] Positioning refers to the process through which people can adopt, resist and offer the subject positions made available in discourses and master narratives." It is, however, impossible to measure this process of positioning via questionnaires. Therefore, we measure career identity by its outcomes: as the commitment a person has toward specific occupational activities or a specific career. We have operationalised career identity in terms of experienced security with regards to self-knowledge, the current course of study and future work, and the self-confidence derived from this. Career identity was measured with an instrument, consisting of ten items. Example items are: "My heart is in the work I'm learning to do," "I know how my future as career man or woman will look like" and "Due to my study I have confidence in my future."

Certainty of career choice is measured with the instrument developed by Germeijs and Verschueren (2007). The response categories of the items vary from 1 to 6 . Example items are: "Could your study direction choice change nevertheless?" $(1=$ certainly, $2=$ with little difficulty, $3=$ probably yes, $4=$ probably no, $5=$ no hard, $6=$ certainly not), and "Are you sure about your study direction choice?" $(1=$ definitely, $2=$ yes, $3=\mathrm{a}$ little, $4=$ not really, $5=$ no, $6=$ definitely not) (reversed coded).

Drop-out threat is measured by four items about the intention to quit the present study. For example: "I intend to complete my study no matter what (reversed coded)" and "I will quit my study."

\section{Career-oriented curriculum organization}

The degree to which a curriculum's organization was practice- (eight items) and inquiry-based (seven items) was evaluated by students as well as their teachers with the same questions. The theoretical framework provided insight into characteristics of curriculum organization, and the role of dialogue in student guidance. Relevant items were generated on the basis of these sources. Example items for practice-based curriculum organization are "The university gives me the opportunity to find out in practice what kind of work best suits me" and "Experiences outside the university (like work, hobbies and working as a volunteer) are recognized in my study." Example items for inquiry-based curriculum organization, are: "In the program I can make choices about what I learn" and "I have my own learning goals that differ from others." In addition, students were asked how many job placements they had had.

Career-oriented guidance. Students were asked with whom and how often they talk about their learning and/or professional career (never, one to four times a year, monthly
Career learning environment

301 
JARHE

6,2

302 or weekly) with a university career counselor, a career coach (often a teacher), a mentor (also a teacher), a practical guide at the workplace, a teacher or with fellow students in a group conversation. They were asked who determines the content of the career counseling discussions. Possible responses are as follows: mostly the teacher, slightly more often the teacher, both equally divided, slightly more often the student, mostly the student. Then students were asked to what extent certain contents and forms are addressed in the career conversation. Forms of conversation that were measured were: helping form (eight items) and reflective-active form (six items). Example items from the helping form include: "My teacher give me lots of information about possible further education." Example items for the reflective-active form: "My teacher makes me think about my future" and "My teacher encourages me to learn new things that I find challenging." Contents of conversations that were measured, were study performance (five items), images about self and future (six items), and concrete actions regarding work and career (six items).

\section{Personal- and situation-bound factors}

Besides the characteristics of the learning environment previously mentioned, personal variables play a role in whether career competencies are learned. First, the degree to which students develop a career depends on their gender. From research done by Patton et al. (2004) it became clear that girls score higher on competence with regards to making career choices than boys, however, male students turned out to be more sure of their career choices. Age is also related to career choice and competence: the older students are, the better they prepare for career choices (Creed et al., 2005) and the more sure they are about their careers (Rowland, 2004). Patton et al. (2004) show that an internal locus of control contributes to the career planning, self-knowledge, knowledge of the work attitude and better career choices. Rotter (1966) uses the concept "locus of control" to express how people perceive the connection between their own actions and the resulting outcomes. If a person attributes success or failure to his own actions, one speaks of an internal locus of control. Internal locus of control was measured by six items, used and tested in Dutch education by Den Hertog (1992). Achievements were used as indicators of cognitive abilities based on the assumption that the degree to which individuals develop competencies might be partly dependent upon their cognitive abilities (Van Merriënboer and De Croock, 2002). Students were therefore asked to respond to the statement: "In the past 3 months, I received only pass grades."

Situational variables were year of study and the type of program that students were participating in. The programs were divided into the following groups: technical studies, economics, agriculture, healthcare and education.

\section{Statistical analyses}

To investigate the extent to which career competencies contribute to career identity, learning motivation, certainty of career choice and threat of drop out, regression analyses were carried out. The four career outcome scales were used as dependent variables and the variables describing career competencies and the learning environment were used as independent variables. Individual- and situational- characteristics (gender, age, previous education, locus of control, study results, and study year and programtype) were included as potential confounders.

The total amount of explained variance was examined, and a block-wise regression was also employed to establish the contribution (to the explained variance) of career competencies in addition to the learning environment characteristics, and the personal 
and situational characteristics. Due to the hierarchical nature of the data (students within classes within universities), multi-level regression was conducted, using the MLWIN v.2.0 program (Rasbash et al., 2005). All continuous variables were normalized to a mean of zero and a standard deviation of 1.0. Because the explorative nature of the study, all hypotheses were tested two-sided and $p$-values $<0.05$ were considered to be significant.

\section{Results}

Sample accrual

A total of 4,820 students from different departments of 11 universities of applied sciences participated in the study. The students are studying at the departments of Healthcare (22 percent), Technical Studies ( 24 percent), Economics (30 percent), Education (16 percent) and Agriculture (8 percent). Of all students at Dutch universities of applied sciences in the course year 2008-2009 22.4 percent are registered in Health Care, 16.4 percent in Technical Studies, 37.2 percent in Economics, 1.2 percent in Agriculture and 22.8 percent in Education (Centraal Bureau voor de Statistiek (CBS), 2010, p. 254). In the research group, students taking Economics and Education are somewhat underrepresented and those taking Technical Studies and Agriculture are over-represented.

\section{Sample characteristics}

Student characteristics, characteristics of their university, and characteristics of their learning environment are displayed in Table I. Slightly fewer than half of the responding students were male, and 18 percent of the students have at least one parent who is born outside The Netherlands. Their average age was 21 years; this variable is also quite skewed, with a number of students being older than 30 years. The previous education of most of the students is general secondary education: 56 percent have an education from a school of higher general secondary education (HGSE) and 12 percent have pre-university education (PUE). Nearly 29 percent of the students completed secondary vocational training and are therefore certified professionals, only at a lower level than their current study trains them for. The research group as it relates to previous schooling, gender and age, accurately represents the student population involved in Dutch universities of applied sciences (CBS, 2010, p. 254).

Two-third of the students score reasonably high on internal locus of control $(>3)$, the average score is 3.25 on a scale from 1 to 4 . The learning achievements are, for most of students, (60 percent) satisfactory for the most part; 11 percent of the students have mostly low marks and 24 percent of the students have only high marks. A large group (41 percent) of students are in their second year of study; only 12 percent are first year students, 22 percent are in their third year and 25 percent are in their fourth year or have studied for more than four years.

All multi-item scales have an adequate Cronbach's $\alpha$ (i.e. $\geqslant 0.70$ ), with the exception of the inquiry-based curriculum scale, which only had an alpha equal to 0.68 .

\section{Regressions}

The regression coefficients and standards errors for the multi-level regressions for each of the independent variables are shown in Table II. The percentage explained variance for the four dependent variables varies between 6 percent (drop-out threat) and 29 percent (career identity), which may be characterized as having a small to medium effect size (Cohen, 1988). The amount of variance due to differences between universities and between classes is negligible, even though the class variance is mostly statistically significant.
Career learning environment 
JARHE

6,2

\begin{tabular}{|c|c|c|c|c|c|}
\hline & & & $\begin{array}{c}\% \\
\text { missing }\end{array}$ & $\begin{array}{c}\text { Cronbach's } \\
\alpha\end{array}$ & $\begin{array}{c}\text { Number } \\
\text { items }\end{array}$ \\
\hline Student characteristics & $n$ & $\%$ & & & \\
\hline Gender Male & 2,256 & 46.8 & 1 & & 1 \\
\hline Ethnicity Non-Dutch & 842 & 17.5 & 1.6 & & 1 \\
\hline Preliminary education & & & 1.3 & & \\
\hline Higher general sec. education & 2,683 & 55.9 & & & \\
\hline Pre-university education & 575 & 11.9 & & & \\
\hline Secondary vocational education & 1,390 & 28.8 & & & 1 \\
\hline \multirow[t]{2}{*}{ Rest } & 100 & 3.4 & & & \\
\hline & Mean & $\mathrm{SD}$ & & & \\
\hline Age & 20.9 & 2.8 & 3.6 & & 1 \\
\hline Internal locus of control & 3.25 & 0.43 & 1 & 0.70 & 6 \\
\hline Learning achievement & 2.99 & 0.87 & 0 & & 1 \\
\hline \multicolumn{6}{|l|}{ Situational characteristics } \\
\hline Study year & 2.71 & 1.18 & 6.5 & & 1 \\
\hline Specialization & $n$ & $\%$ & 0.3 & & 1 \\
\hline Healthcare & 1,050 & 21.8 & & & \\
\hline Technical & 1,180 & 24.5 & & & \\
\hline Economy & 1,409 & 29.2 & & & \\
\hline Education & 789 & 16.4 & & & \\
\hline Agriculture & 378 & 7.8 & & & \\
\hline Learning environment characteristics & Mean & SD & & & \\
\hline Internships (in months) & 4.78 & 7.15 & 9.5 & & 1 \\
\hline Practice-based curriculum & 2.61 & 0.57 & 1.9 & 0.74 & 8 \\
\hline Inquiry-based curriculum & 2.39 & 0.51 & 0.2 & 0.68 & 7 \\
\hline \multicolumn{6}{|l|}{ Quantity of guidance conversation with career } \\
\hline counselor & 2.29 & 0.76 & 0.6 & & 1 \\
\hline Quantity of guidance conversation with mentor & 1.68 & 0.87 & 1.3 & & 1 \\
\hline Student-led conversation & 2.67 & 1.32 & 11.6 & & 1 \\
\hline Helping form of conversation & 2.54 & 0.64 & 1.5 & 0.88 & 8 \\
\hline Career form of conversation & 2.48 & 0.63 & 1.5 & 0.82 & 6 \\
\hline Content of conversation: study & 2.77 & 0.58 & 4.5 & 0.70 & 5 \\
\hline Content of conversation: self and future & 2.24 & 0.65 & 5.2 & 0.81 & 6 \\
\hline Content of conversation: work and career & 2.21 & 0.66 & 5.4 & 0.85 & 6 \\
\hline Career competencies & Mean & $\mathrm{SD}$ & & & \\
\hline Career reflection & 2.57 & 0.50 & 0.1 & 0.84 & 11 \\
\hline Work exploration & 2.43 & 0.55 & 0.1 & 0.79 & 7 \\
\hline Career action & 2.25 & 0.55 & 0 & 0.74 & 7 \\
\hline Career networking & 2.38 & 0.66 & 0.3 & 0.83 & 6 \\
\hline \multicolumn{6}{|l|}{ Career outcomes } \\
\hline Learning motivation & 2.74 & 0.49 & 0 & 0.81 & 10 \\
\hline Career identity & 2.76 & 0.80 & 0 & 0.81 & 10 \\
\hline Certainty of career choice (1-5 scale) & 4.79 & 0.49 & 0 & 0.81 & 5 \\
\hline Drop-out threat & 1.20 & 0.38 & 0.2 & 0.77 & 4 \\
\hline
\end{tabular}

\section{Career competencies}

Regarding the research question about the contribution of career competencies of students to career outcome variables, the results show that career competencies explain the variance on the scores of outcome variables. Career action and work exploration are significantly beneficial for three outcomes, with moderate effect sizes. Students who 


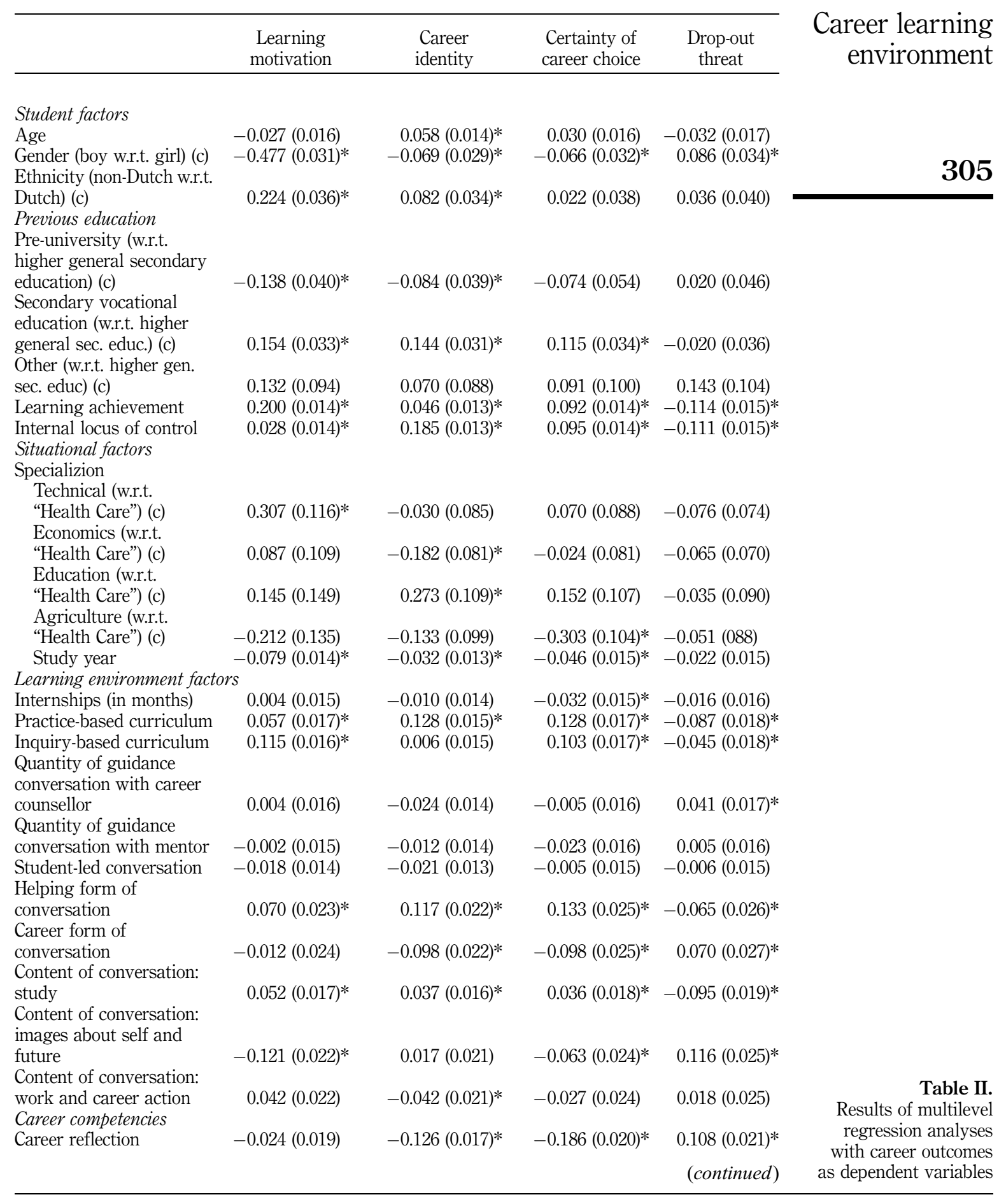


JARHE

6,2

$\underline{306}$

Table II.

\begin{tabular}{|c|c|c|c|c|}
\hline & $\begin{array}{l}\text { Learning } \\
\text { motivation }\end{array}$ & $\begin{array}{l}\text { Career } \\
\text { identity }\end{array}$ & $\begin{array}{l}\text { Certainty of } \\
\text { career choice }\end{array}$ & $\begin{array}{c}\text { Drop-out } \\
\text { threat }\end{array}$ \\
\hline Work exploration & $0.064(0.022)^{*}$ & $0.209(0.020)^{*}$ & $0.107(0.023) *$ & $-0.013(0.024)$ \\
\hline Career action & $0.174(0.020)^{*}$ & $0.142(0.018)^{*}$ & $0.085(0.021)^{*}$ & $-0.005(0.022)$ \\
\hline Career networking & $0.002(0.019)$ & $0.137(0.017)^{*}$ & $0.099(0.020)^{*}$ & $-0.016(0.021)$ \\
\hline School sector variance & $0.010(0.009)$ & $0.002(0.004)$ & $0.010(0.005) *$ & $0.000(0.000)$ \\
\hline Class variance & $0.039(0.011)^{*}$ & $0.027(0.008)^{*}$ & $0.003(0.003)$ & $0.016(0.006)^{*}$ \\
\hline Residual variance & $0.746(0.016)^{*}$ & $0.652(0.014)^{*}$ & $0.849(0.018)^{*}$ & $0.918(0.019)^{*}$ \\
\hline $\begin{array}{l}\text { Total explained variance } \\
\text { Model improvement }\end{array}$ & $0.216(22 \%)$ & $0.287(29 \%)$ & $0.131(13 \%)$ & $0.055(6 \%)$ \\
\hline $\begin{array}{l}\text { through addition of all } \\
\text { variables } \\
\text { Model improvement }\end{array}$ & $1,115(\mathrm{df} 28)^{*}$ & $1,613(\mathrm{df} 28)^{*}$ & 674 (df 28)* & $282(\mathrm{df} 28)^{*}$ \\
\hline $\begin{array}{l}\text { trough adaition career } \\
\text { competencies }\end{array}$ & $174(\mathrm{df} 4)^{*}$ & $553(\mathrm{df} 4)^{*}$ & $156(\mathrm{df} 4)^{*}$ & $35(\mathrm{df} 4)^{*}$ \\
\hline
\end{tabular}

Notes: $n=4,650$. All continuous variables were transformed to $Z$-scores. Regression coefficients are shown, with the standard errors between parentheses. (c), categorical variable. ${ }^{*} p<0.05$

explore work demands, opportunities and developments, and judge their career behavior as pro-active appear to be committed to their current study (learning motivation), to be certain about the choice of their study direction (certainty of career choice) and to have - based on knowledge about themselves and work - confidence in their future career (career identity). Networking proves to be related to the development of a career identity and certainty of career choice. A negative relationship between career reflection on and career identity as well certainty of career choice, and the positive relation with drop-out threat is found. This can probably be explained by the fact that students, who have not developed a career identity yet and are, therefore, uncertain about their career choice and consider to quit their study, are more likely to reflect on their aptitudes and motives (career reflection).

\section{Career learning environment}

The results show that different aspects of the learning environment contribute to career outcome variables. A practice-based and inquiry-based curriculum proves to contribute to learning motivation, career identity (only practice-based curriculum significantly) and certainty of career choice. Moreover, students in a practice-based and inquiry-based curriculum are less likely to intend to quit their study. Also guidance conversation explains the career outcomes, but in the opposite way one should expect. The results show that helping - that is affective and informative - conversations about the study contribute to the career outcomes in a positive way; a reflective and activating form of conversation about self and future image or work and career action, however, does not. Students having more often conversations with their career counsellor are students who intend to quit their study.

\section{Situational and personal factors related to learning and career outcomes}

Both study direction and study year explain the variance on the career outcomes. Students in technical studies claim to be more motivated for learning. Students in educational studies develop a stronger career identity, unlike students in economical studies. Students in agricultural studies are less certain about their choice for this study. 
As the study progresses, students seem to get less motivated, less confident about their future career based on the knowledge about themselves and work (career identity) and less certain about the study direction they have chosen.

With regard to personal factors, higher scores on learning achievement and internal locus of control are positively related to the career outcome measures, except for drop-out threat which is negatively related. Students who attended secondary vocational education as previous education, are more motivated for learning, have a stronger career identity and are more certain about their study direction choice; students that attended pre-university education are less motivated and have lower scores on career identity.

Non-Dutch students appear to experience more learning motivation and a stronger career identity than Dutch students. Older students have a stronger career identity. And girls are more motivated for learning, experience a stronger career identity, are more certain about their career choice and are less likely to intend to drop out than male students.

To compensate for the results of personal factors on career outcomes, aspects of career learning environment, with similar effect sizes, might be implemented. For example, older students have a stronger career identity. To compensate for this lack among younger students, the latter need to have a more career practice-based curriculum. Also, boys are less certain about their study direction choice. They might need, for example, more helping conversations about their study.

The lack of learning motivation of male and indigenous students, might be compensated by stimulating participation in their learning, i.e. in the promotion of an inquiry-based curriculum.

\section{Conclusion and discussion}

A high drop-out rate and a lack of learning motivation are often seen as the result of an absence of a clearly formulated career wish and a lack of perspective on a future direction. That is why, in recent years, a lot is being invested in providing guidance to stimulate students in their career development. Although a narrative career approach is preferred by leading scientists and a majority of career counselors, such an approach is considerably more expensive than providing information. As a result, the career guidance offered is still predominantly inspired by the trait-and-factor approach. But providing information does not have the expected outcomes at all: students overall are negative about the guidance they receive and consider it to a large extent useless (Mittendorff, 2010; Mittendorff et al., 2008, 2011; Winters et al., 2009; Foskett, 2004), while the drop-out rates have not changed significantly (CBS, 2010). Until now it is to a large degree unclear what the effects of various guidance and counseling interventions are and, therefore, what kind of investments have to be made. Is this paper we have investigated the relationship between career competencies on the one hand and career identity, learning motivation, certainty of career choice and threat of drop out on the other hand.

The question whether career competencies are related to career identity, learning motivation, certainty of career choice and threat of drop out is answered affirmatively in this study for the competencies work exploration, career action and networking. Despite relevant personal factors, as internal locus of control and learning achievements, students who explore work opportunities and are pro-active in their career, prove to experience a stronger career identity, feel more certain about their career choice and are more motivated for learning. Networking is related to career identity and certainty of career choice. A negative relationship is found between career reflection and career identity as well as certainty of career choice. Moreover, there is
Career learning environment 
JARHE

6,2

308 positive relation between career reflection and drop-out threat. These findings might be explained by the fact that students, who have not yet developed a career identity and are, therefore, uncertain about their career choice and consider quitting their study, are more likely to reflect on their aptitudes and motives (career reflection).

The learning environment, too, contributes to career outcome variables. Students who participate in a practice-based and inquiry-based curriculum, and have helping that is affective and informative - conversations about their study with their teachers, are more motivated for learning, are more certain of their career choice, and are less likely to quit their study. Moreover, students in a practice-based curriculum have a stronger career identity.

Against one would expect, we found that a reflective and activating form of conversation about self and future and about concrete actions regarding work and career, is negatively related to the career outcome variables. In earlier analyses on the relationship between the form and content of career conversations and career competencies, we found a positive relation between a reflective and stimulating conversation about self and future, and work and career actions on the one, and career competencies on the other hand. A helping form of conversation about study results was negatively related to career competencies (Kuijpers and Meijers, 2012). Probably, a helping and study focussed guidance gives students a feeling of certainty and motivation, but does not stimulate students to develop their career. Career focussed guidance stimulates the career development of students, but results apparently in feeling of uncertainty and less motivation for learning, probably mainly in students that are not active in their career development. Further research is necessary to explain these findings.

A limitation of this study is that, due to the cross-sectional design with no control group, no strong evidence for effectiveness can be presented. Moreover, the lack of well validated instruments limits the value of the results. The explained variance of the outcome variables, however, does indicate that there are relationships between career competencies and career learning environment on one hand, and career identity, learning motivation and certainty of choices on the other. To be more certain of the nature and extent of these relationships, the research instruments used in this study need to be further developed and tested and more complex conceptual models have to be developed. Moreover, efforts have to be made to improve the overall model fit of career competencies. One could consider variations on the four factor structure that was used here. To account for the differences between institutes, school level was incorporated in the multi-level analyses. However, the non-significant contribution on school level might be due to the limited number of institutes participating in this study. In further research more institutes should be included.

A further limitation of this study is caused by possible influences of self-selection in a two-fold way. First, some students are seeking guidance themselves, while others are in programs in which career development is built-in in the curriculum. Further study might explore differences between programs in which career counseling/career development is a built-in curricular requirement vs programs in which students opt to seek career guidance. Second, students have to choose between a university of applied sciences or a research university. However, in both types of university practice- and inquiry-based curricula are rare. Therefore, the majority of students has no option to choose for a practice- and/or inquiry-based curriculum. For a minority of students, however, there can be effects of self-selection. As a consequence, claims about educational effects must be made with caution (see DesJardins et al., 2002). 


\section{References}

Amundson, N.E. (2010), Metaphor Making: Your Career, Your Life, Your Way, Ergon Communications, Richmond.

Argyris, C. and Schön, D. (1974), Theory in Practice: Increasing Professional Effectiveness, Jossey-Bass, San Francisco, CA.

Arthur, M.B., Inkson, K. and Pringle, J. (1999), The New Careers - Individual Action and Economic Change, Sage, London.

Arthur, M.B., Khapova, S.N. and Wilderom, C.P.M. (2005), "Career success in a boundaryless career world”, Iournal of Organizational Behaviour, Vol. 26 No. 2, pp. 177-202.

Ashforth, B.E., Harrison, S.H. and Corley, K.G. (2008), "Identification in organizations: an examination of four fundamental questions", Journal of Management, Vol. 34 No. 3, pp. 325-374.

Beck, U. (1994), "The reinvention of politics - towards a theory of reflexive modernisation”, in Beck, U., Giddens, A. and Lash, S. (Eds), Reflexive Modernisation, Polity Press, Cambridge, pp. 1-56.

Bimrose, J. and Hearne, L. (2012), "Resilience and career adaptability: qualitative studies of adult career counseling", Journal of Vocational Behavior, Vol. 81 No. 3, pp. 338-344.

Bimrose, J., Barnes, S.-A., Hughes, D. and Orton, M. (2004), What is Effective Guidance? Evidence from Longitudinal Case Studies in England, Warwick Institute for Employment Research/ University of Warwick, Coventry.

Brusoski, G.C., Golin, A.K., Gallagher, R.P. and Moore, M. (1993), "Career group effects on career indecision: career maturity, and locus of control of undergraduate clients", Iournal of Career Assessment, Vol. 1 No. 3, pp. 309-320.

Centraal Bureau voor de Statistiek (CBS) (2010), Statistisch Jaarboek 2010 (Statistical Year Book 2010), CBS, s-Gravenhage/Heerlen.

Cochran, L. (1997), Career Counseling: A Narrative Approach, Sage, Thousand Oakes, CA.

Cohen, J. (1988), Statistical Power Analysis for the Behavioral Sciences, 2nd ed., Lawrence Erlbaum Associates, Hillsdale, NJ.

Creed, P., Prideaux, L. and Patton, W. (2005), "Antecedents and consequences of different decisional states in adolescence: a longitudinal study", Iournal of Vocational Behavior. Vol. 67 No. 3, pp. 397-412.

Davies, B. and Harré, R. (1990), "Positioning: the discursive production of selves", Iournal for the Theory of Social Behaviour, Vol. 20 No. 2, pp. 43-63.

Dawis, R.V. (1996), "Vocational psychology, vocational adjustment, and the workforce: some familiar and unanticipated consequences", Psychology. Public Policy. and Law, Vol. 2 No. 3, pp. 229-248.

De Bruijn, E., Overmaat, M., Glaudé, M., Heemskerk, I., Leeman, Y., Roeleveld, J. and Venne, L. van de (2005), "Krachtige leeromgevingen in het middelbaar beroepsonderwijs: vormgeving en effecten (Strong learning environments in secondary vocational education: design and effects)", Vol. 82 No. 1, pp. 77-95.

Den Hertog, P.C. (1992), “De 'IE-18 locus of control'-vragenlijst: betrouwbaarheid en validiteit van een gewijzigde versie. (The ÍE-18 locus of control questionnaire)", Nederlands Tijdschrift voor de Psychologie, Vol. 47 No. 2, pp. 82-87.

DesJardins, S.L., McCall, B.P., Ahlburg, D.A. and Moye, M.J. (2002), "Adding a timing light to the 'Tool Box'”, Research in Higher Education, Vol. 43 No. 1, pp. 83-114.

Dieleman, A. and Meijers, F. (2005), "Paradise lost: youth in transition in The Netherlands", in Bagnall, N. (Ed.), Youth Transition in a Globalised Marketplace, Nova Science, New York, NY, pp. 75-99.
Career learning environment

309 
JARHE

6,2

310
European Commission and OECD (2004), Career Guidance: A Policy Handbook, OECD and European Commission Publication, Paris and Luxembourg.

Foskett, N. (2004), "IAG (Information, Advice and Guidance) and young people's participation decisions 14-19", Nufield review of 14-19 education and training working paper, University of Southampton, Southampton.

Germeijs, V. and Verschueren, K. (2007), "High school students' career decision-making process: a longitudinal study of one choice", Iournal of Vocational Behavior, Vol. 68 No. 2, pp. 189-204.

Giddens, A. (1991), Modernity and Self-Identity - The Self and Society in the Late Modern Age, Polity Press, London.

Guindon, M.H. and Hanna, F.J. (2002), "Coincidence, happenstance, serendipity, fate, or the hand of god: case studies in synchronicity", Career Develobment Quarterlv, Vol. 50 No. 3, pp. 195-208.

Gysbers, N.C. and Henderson, P. (2005), "Designing, implementing, and managing comprehensive school guidance and counselling programme", in Sink, C.A. (Ed.), Contemporary School Counselling: Theory, Research, and Practice, Houghton Mifflin, Boston, MA, pp. 151-188.

Hargreaves, A. (2003), Teaching in the Knowledge Society: Education in the Age of Insecurity, Teachers College Press, New York, NY.

Harrington, T.F. and Harrigan, T.A. (2006), "Practice and research in career counseling and development - 2005”, Career Develobment Quarterlv Vol. 55 No. 2, pp. 98-167.

Hermans, H.J.M. and Hermans-Konopka, A. (2010), Dialogical Self Theorv. Positioning and Counter-Positioning in a Globalizing Societv, Cambridge University Press, Cambridge, MA.

Hughes, D., Bosley, S., Bowes, L. and Bysshe, S. (2002), The Economic Benefits and Guidance. Research Report, Centre for Guidance Studies, University of Derby, Derby.

Hughes, K.L. and Karp, M.M. (2004), School-Based Career Development: A Synthesis of the Literature, Columbia University Institute on Education and the Economy Teachers College, New York, NY.

Irving, B.A. and Malik, B. (Eds) (2005), Critical Reflections on Career Education and Guidance: Promoting Social Iustice within a Global Economv, RoutledgeFarmer, London and New York, NY.

Jarvis, P. and Keeley, E.S. (2003), "From vocational decision making to career building: blueprint, real games, and school counselling", Professional School Counselling, Vol. 6 No. 4, pp. 244-251.

Johnson, D. (2009), "Bridging the learning divide: a study into adult learning and peer mediation in the workplace", in Maclean, R. and Wilson, D.N. (Eds), International Handbook of Education For the Changing World of Work. Bridging Academic and Vocational Learning, Springer, New York, NY, pp. 219-234.

Killeen, J. (1996), “The learning and economic outcomes of guidance”, in Watts, A.G., Law, B., Killeen, J., Kidd, J.M. and Hawthorn, R. (Eds), Rethinking Careers Education and Guidance. Theory, Policy and Practice, Routledge, London and New York, NY, pp. 72-94.

Killeen, J., White, M. and Watts, A.G. (1992), The Economic Value of Careers Guidance, Policy Studies Institute/Department for Education and Employment, London.

Killeen, J., Edwards, A., Barnes, A. and Watts, A.G. (1999), "Evaluating the UK national pilot of The Real Game: Technical report on the quantitative analysis of learning outcomes", NICEC Project Report, Careers Research and Advisory Centre, Cambridge, MA.

Krieshok, T.S., Black, M.D. and McKay, R.A. (2009), "Career decision making: the limits of rationality and the abundance of non-conscious processes", Journal of Vocational Behavior. Vol. 76 No. 3, pp. 275-290. 
Kronman, A.T. (2007), Education's End: Why Our Colleges and Universities Have Given Up on the Meaning of Life, Yale University Press, New Haven, CT and London.

Krumboltz, J.D. and Worthington, R. (1999), "The school-to-work transition from a learning theory perspective", Career Development Quarterly, Vol. 47 No. 4, pp. 312-326.

Kuijpers, M. (2007), Loopbaanontwikkeling in het beroepsonderwijs (Career Learning in Vocatioal Education), De Haagse Hogeschool, Den Haag.

Kuijpers, M. and Meijers, F. (2012), "Learning for now or later? Career competencies among students in higher vocational education in the Netherlands", Studies in Higher Education, Vol. 37 No. 4, pp. 449-467.

Kuijpers, M., Meijers, F. and Gundy, C. (2011), "The relationship between learning environment and career competencies of students in vocational education", Iournal of Vocational Behavior, Vol. 78 No. 1, pp. 21-30.

Kuijpers, M.A.C.T. and Scheerens, J. (2006), "Career competencies for the modern career", Iournal of Career Develobment, Vol. 32 No. 3, pp. 303-319.

LaPointe, K. (2010), "Narrating career, positioning identity: career identity as a narrative practice", Journal of Vocational Behavior, Vol. 77 No. 1, pp. 1-9.

Law, B. (2005), "Integrated information, advice \& guidance 14-19 and beyond", available at: www.hihohiho.com (accessed December 5, 2010).

Lengelle, R., Meijers, F., Poell, M. and Post, M. (2013), "The effects of creative, expressive, and reflective writing on career learning: an explorative study", Iournal of Vocational Behavior, Vol. 83 No. 4, pp. 419-427.

Lent, R.W., Larkin, K.C. and Hasegawa, C.S. (1986), "Effects of a 'focused interest' career course approach for college students", Vocational Guidance Quarterlv Vol. 34 No. 3, pp. 151-159.

Light, R. (2001), Making the Most of College. Students Speak their Minds, Harvard University Press, Cambridge, MA.

McWhirter, E.H., Rasheed, S. and Crothers, M. (2000), "The effects of high school career education on social-cognitive variables", Journal of Counseling Psychology, Vol. 47 No. 3, pp. 330-341.

Meijers, F. (2001), "The effects of the marketisation of career guidance services in The Netherlands", International Journal for the Advancement of Counselling, Vol. 23 No. 2, pp. 131-149.

Meijers, F. (2008), "Mentoring in Dutch vocational education: an unfulfilled promise", British Iournal of Guidance and Counselling, Vol. 36 No. 3, pp. 235-252.

Meijers, F. and Lengelle, R. (2012), "Narratives at work: the development of career identity", British Journal of Guidance and Counselling, Vol. 40 No. 2, pp. 157-177.

Meijers, F., Kuijpers, M. and Gundy, C. (2013), "The relation between career competencies, career identity, motivation and quality of choice", International Iournal for Educational and Vocational Guidance, Vol. 13 No. 1, pp. 47-66.

Mitchell, L.K. and Krumboltz, J.D. (1996), "Social learning approach to career decision making: Krumboltz's Theory", in Brown, D., Brooks, L. and Associates (Eds), Career Choice and Development, Jossey-Bass, San Francisco, CA, pp. 145-196.

Mitchell, K.E., Levin, A.S. and Krumboltz, J.D. (1999), "Planned happenstance: constructing unexpected career opportunities", Journal of Counselling and Development, Vol. 77 No. 2, pp. 115-124.

Mittendorff, K. (2010), "Career conversations in senior secondary vocational education", $\mathrm{PhD}$-thesis, School of Education University of Technology Eindhoven, Eindhoven.

Mittendorff, K., den Brok, P. and Beijaard, D. (2011), "Students' perceptions of career conversations with their teachers", Teaching and Teacher Education, Vol. 27 No. 3, pp. 515-523.
Career learning environment

311 
JARHE

6,2

312

Mittendorff, K., Jochems, W., Meijers, F. and den Brok, P. (2008), "Differences and similarities in the use of the portfolio and personal development plan for career guidance in various vocational schools in The Netherlands", Iournal of Vocational Education and Training, Vol. 60 No. 1, pp. 75-91.

Nichols, S.L. and Berliner, D.C. (2007), Collateral Damage: How High Stakes Testing Corrupts America's Schools, Harvard University Press, Cambridge, MA.

Oliver, L.W. and Spokane, A.R. (1988), "Career-intervention outcomes: what contributes to client gain?”, Journal of Counseling Psvchologv Vol. 35 No. 4, pp. 447-462.

Organisation for Economic Co-operation and Development (OECD) (2004), Career Guidance and Public Policy: Bridging the Gap, OECD Publishing, Paris.

Organisation for Economic Co-operation and Development (2006), Are Students Ready for a Technology-Rich World? What PISA Studies Tell Us, OECD Publishing, Paris.

Patton, W., Bartrum, D.A. and Creed, P.A. (2004), "Gender differences for optimism, self-esteem, expectations and goals in predicting career planning and exploration in adolescents", International Iournal for Educational and Vocational Guidance, Vol. 4 No. 2, pp. 193-209.

Parsad, B., Alexander, D., Farris, E. and Hudson, L. (2003), High School Guidance Counselling. (NCES 2003-015), U.S. Department of Education, National Center for Education Statistics, Washington, DC.

Prawat, R.S. (1998), "Current self-regulation views of learning and motivation viewed through a Deweyan lens: the problems with dualism", American Educational Research Journal, Vol. 35 No. 2, pp. 199-224.

Pryor, R.G.L. and Bright, J.E.H. (2011), The Chaos Theory of Careers, Routledge, New York, NY and London.

Rasbash, J., Charlton, C., Browne, J.W., Healy, M. and Cameron, B. (2005), MLwiN Version 2.02, Centre for Multilevel Modelling, University of Bristol, Bristol.

Reid, H. and West, L. (2011), "Struggling for space: narrative methods and the crisis of professionalism in career guidance in England", British Journal of Guidance and Counselling, Vol. 39 No. 5, pp. 397-410.

Riverin-Simard, D. (2000), "Career development in a changing context of the second part of working life", in Collin, A. and Young, R.A. (Eds), The Future of Career, Cambridge University Press, Cambridge, pp. 115-130.

Rotter, J.B. (1966), "Generalized expectancies for internal versus external control of reinforcement", Psychological Monographs, Vol. 80 No. 1, pp. 1-28.

Rowland, K.D. (2004), "Career decision-making skills of high school students in the Bahamas", Iournal of Career Develobment, Vol. 31 No. 1, pp. 1-13.

Sampson, J., Reardon, R.C., Peterson, G.W. and Lenz, J. (2003), Career Counselling and Services: A Cognitive Information Processing Approach - Accountability and Evaluation in Career Services, Wadsworth Thomson Learning, Florida State University, Tallahassee.

Savickas, M. (1990), "The career-decision making course: description and field test", Career Develobment Quarterlv Vol. 47 No. 4, pp. 326-336.

Savickas, M. (2002), "Career construction: a developmental theory of vocational behaviour", in Brown, D.A. (Ed.), Career Choice and Development, Jossey-Bass, San Francisco, CA, pp. 149-205.

Savickas, M.L. (2013), "Career construction theory and practice", in Brown, S.D. and Lent, R.V. (Eds), Career Devolopment and Counselling: Putting Theory and Research to Work, John Wiley and Sons, Hoboken, NJ, pp. 147-185.

Savickas, M.L., Nota, L., Rossier, J., Dauwalder, J.P., Duarte, M.E., Guichard, J., Soresi, S., Van Esbroeck, R. and Van Vianen, A.E.M. (2010), "Life designing: a paradigm for career Construction in the 21th century", Journal of Vocational Behavior, Vol. 75 No. 2, pp. 239-250. 
Schwartz, B. (2004), The Paradox of Choice, Harper Perennial, New York, NY.

Sennett, R. (1998), The Corrosion of Character. The Personal Consequences of Work in the New Capitalism, Norton, London.

Sharf, R.S. (1997), Applying Career Development Theory to Counseling, Brooks/Cole, Pacific Grove, CA.

Stuss, D.T. and Anderson, V. (2003), "The frontal lobes and theory of mind: developmental concepts from adult focal lesion research", Brain and Cognition, Vol. 55 No. 1, pp. 69-83.

Sultana, R.G. (2004), Guidance Policies in the Learning Society: Trends, Challenges and Responses Across Europe, Cedefop, Thessaloniki.

Trilling, B. and Fadel, C. (2009), 21st Century Skills: Learning for Life in Our Times, Jossey-Bass, San Francisco, CA.

Van Beek, K. (1993), To be Hired or Not to be Hired; The Employer Decides, Universiteit van Amsterdam, Amsterdam.

Van Merriënboer, J.J.G. and de Croock, M.B.M. (2002), "Performance-based ISD: 10 steps to complex learning", Performance Improvement, Vol. 41 No. 1, pp. 33-38.

Wagner, T. (2010), The Global Achievement Gap, Basic Books, New York, NY.

Watts, A.G. and Sultana, R.G. (2004), "Career guidance policies in 37 countries: contrasts and common themes", International Journal for Educational and Vocational Guidance, Vol. 4 No. 2, pp. 105-122.

Whiston, S.C., Sexton, T.L. and Lasoff, D.L. (1998), "Career-intervention outcome: a replication and extension of Oliver and Spokane (1988)", Journal of Counseling Psychology. Vol. 45 No. 2, pp. 150-165.

Wijers, G. and Meijers, F. (1996), “Career guidance in the knowledge society”, British Iournal of Guidance and Counselling, Vol. 24 No. 2, pp. 185-198.

Winters, A., Meijers, F., Kuijpers, M. and Baert, H. (2009), "What are vocational training conversations about? Analysis of vocational training conversations in Dutch vocational education from a career learning perspective", Iournal of Vocational Education and Training, Vol. 61 No. 3, pp. 247-266.

\section{Corresponding author}

Dr Frans Meijers can be contacted at: fj.meijers@xmsnet.nl

To purchase reprints of this article please e-mail: reprints@emeraldinsight.com

Or visit our web site for further details: www.emeraldinsight.com/reprints 